\title{
Anodic Current Efficiency in the Counterflow Electrolysis of Uranyl Chloride Solutions*
}

\author{
By Walter J. Hamer
}

\begin{abstract}
Anodic current efficiency or the chlorine-oxygen ratio in the electrolysis of aqueous solutions of uranyl chloride was determined by a counterflow method at a temperatuie of $25^{\circ} \mathrm{C}$. Because of the hydrolysis of dissolved chlorine, measurements were made only after sufficient time had elapsed to assure a state of equilibrium. Different concentrations of electrolyte, various electrode materials, and several current densities were employed to ascertain the effects of such changes.

The standard potentials of the oxygen and chlorine electrodes are such that oxygen should be evolved at anodes in the electrolysis of chlorides. However, chlorine is liberated because of the relative magnitudes of the oxygen and chlorine overvoltages. The value of overvoltage is dependent on the electrode material and the nature of the electrode surface. For uranyl chloride the current efficiencies increase in the order: magnetite, are carbon, graphite, metallic carbides, and the platinum metals. Magnetite, the carbides, arc carbon, and graphite erode or pencil during electrolysis. Palladium black and platinum black become dispersed in the electrolyte. The highest current efficiency obtained was 97 percent, and the data indicated that current efficiencies of 100 percent cannot be realized for aqueous solutions of uranyl chloride at $25^{\circ} \mathrm{C}$. The method is general and may be used in the determination of the current efficiency of many electrode processes. The method may also be adapted to the continuous production of gases of known purity.
\end{abstract}

\section{Introduction}

Current efficiency is defined as the ratio of the number of equivalents of a single electrode product to the total possible number of equivalents computed by Faraday's law of electrolysis. Deviations from Faraday's law are caused by simultaneous electrode reactions, by the interaction of anodic and cathodic products, by the diffusion of anodic and cathodic products from one electrode to another so that an electrolytic reversal of electrode processes ensues, and by the phenomena of mixed electrolytic and electronic conductance.

It is well known that current efficiencies depend on the electrode material, the current density, and to lesser extent on the concentration of the electrolyte and the temperature. It is necessary therefore to determine the current efficiency at several concentrations and obtain the current efficiency at a definite concentration by interpolation of the data. Recently, Brewer, Madorsky, and Westhaver [1] ${ }^{1}$ described a method of electrolysis in which the concentration of the electrolyte is maintained constant throughout the electrolysis. They termed their method countercurrent electromigration. They used the method for the enrichment of the potassium isotopes utilizing the difference in the mobilities of the isotopic ions. For a successful application of the method the current efficiencies of the electrode processes must be known. It is the purpose of this paper to show how their method may be applied to the determination of the current efficiency of an electrode process, and how it may be used in the continuous production of a gas of known purity. It is illustrated with aqueous solutions of uranyl chloride. Any other

1 Figures in brackets indicate the literature references at the end of this paper.

*This investigation was sponsored in 1942-43 by the Office of Scientific Research and Development, the National Defense Research Committee, and by the Manhattan Project. The information covered in this document will appear in volume VI, division III of the Manhattan Project Technical Series, as part of a contribution of the National Bureau of Standards. 
chloride, or for that matter many other electrolytes, could be used. No studies of isotope separation were made because the formation of complex ions, the solubility of chlorine, and simultaneous electrode reactions introduce undue complications.

Upon electrolysis of a solution of uranyl chloride, the predominant reaction at the anode is

$$
2 \mathrm{Cl}^{-}=\mathrm{Cl}_{2}+2 \epsilon .
$$

Simultaneously, however, some oxygen is liberated by the reaction

$$
6 \mathrm{H}_{2} \mathrm{O}=4 \mathrm{H}_{3} \mathrm{O}^{+}+\mathrm{O}_{2}+4 \epsilon .
$$

The current efficiency for the production of chlorine, expressed as the chlorine-oxygen ratio in the gas liberated at the anode, was determined for solutions containing 1 equivalent of uranyl chloride in 60 moles of water $\left(0.902 \mathrm{~N}\right.$; density at $25^{\circ} \mathrm{C}=$ $1.1286)$, in 110 moles of water $(0.499 \mathrm{~N}$; density at $\left.25^{\circ} \mathrm{C}=1.0739\right)$, and in 555.1 moles of water $\left(0.1007 \mathrm{~N}\right.$; density at $\left.25^{\circ} \mathrm{C}=1.0071\right) .^{2} \quad$ Electrodes of platinum, platinum black, palladium, palladium black, iridium, platinum-iridium alloy, magnetite, zirconium carbide, tungsten carbide, columbium-tantalum carbide, arc carbon, and various grades of graphite were used at a number of current densities. Loss of chlorine from the gas mixture by solution and the accompanying hydrolysis reaction

$$
\mathrm{Cl}_{2}+\mathrm{H}_{2} \mathrm{O}=\mathrm{HClO}+\mathrm{HCl}
$$

were prevented by electrolyzing for a sufficient time to saturate the solution with chlorine before the samples of gas generated at the anode were taken for analysis.

At the cathode the reaction

$$
\mathrm{UO}_{2}^{++}+4 \mathrm{H}_{3} \mathrm{O}^{+}+2 \epsilon=\mathrm{U}^{+1 \mathrm{v}}+6 \mathrm{H}_{2} \mathrm{O}
$$

or some other type reduction occurs. This was prevented by isolating the cathode from uranyl chloride with hydrochloric acid. The hydrochloric acid formed a boundary with the solution of uranyl chloride.

\section{Electrolytic Method and Drop Rates}

When a solution of uranyl chloride is electrolyzed there is a loss at the anode of $t_{\mathrm{UO}_{2}}^{++}$equivalent of $\mathrm{UO}_{2} \mathrm{Cl}_{2}$ per faraday. Therefore, a more concentrated solution must be added at the anode at the

\footnotetext{
2 Densities of solutions were measured by the Lubricants and Liquid
} Fuels Section of the National Bureau of Standards. proper rate to maintain constant composition of $\mathrm{UO}_{2} \mathrm{Cl}_{2}$. If no $\mathrm{HCl}$ had been added at the cathode there would have been a loss per faraday of $t_{\mathrm{C} 1}-$ equivalent of $\mathrm{UO}_{2} \mathrm{Cl}_{2}$. When $\mathrm{HCl}$ is used, as is the case, there is a loss per faraday of 1 equivalent of $\mathrm{H}^{+}$ions owing to electrolysis, and a gain because of transference of $t_{\mathrm{UO}_{2}}^{++}$equivalent of $\mathrm{UO}_{2}^{++}$and a loss of $t_{\mathrm{C} 1}{ }^{-}$equivalent of $\mathrm{Cl}^{-}$ions. Consequently, a solution must be added at the cathode containing enough $\mathrm{HCl}$ to take care of the loss in $\mathrm{HCl}$ and enough $\mathrm{H}_{2} \mathrm{O}$ to maintain constant the concentration of $\mathrm{UO}_{2} \mathrm{Cl}_{2}$. Also, these solutions must be added at the proper rate.

Calculations of drop rates follow: If we let

$a=$ moles of $\mathrm{H}_{2} \mathrm{O}$ per equivalent weight of $\mathrm{UO}_{2} \mathrm{Cl}_{2}$ in the cell,

$b=$ moles of $\mathrm{H}_{2} \mathrm{O}$ per equivalent weight of $\mathrm{UO}_{2} \mathrm{Cl}_{2}$ that should be added to the anode to maintain a constant composition of $\mathrm{UO}_{2} \mathrm{Cl}_{2}$ in the cell $=a\left(1-t_{\mathrm{UO}_{2}}{ }^{++}\right)$

$$
=a t \mathrm{Cl}^{-} \text {, }
$$

$d=$ equivalent weight of $\mathrm{UO}_{2} \mathrm{Cl}_{2}=170.492$,

$\ell=$ molecular weight of $\mathrm{H}_{2} \mathrm{O}=18.016$,

$F=$ the faraday $=96,500$ ampere-seconds, $t_{\mathrm{UO}_{2}}^{++}=$the transference number of the $\mathrm{UO}_{2}^{++}$ion in $\mathrm{UO}_{2} \mathrm{Cl}_{2}$,

$t_{\mathrm{Cl}}{ }^{-}=$the transference number of the $\mathrm{Cl}^{-}$ion in $\mathrm{UO}_{2} \mathrm{Cl}_{2}$,

$W=$ weight of drop in grams of a solution of $\mathrm{UO}_{2} \mathrm{Cl}_{2}$ added at the anode, we may derive the equation:

$$
\frac{W F}{\operatorname{amp}\left(d+\text { aet }_{\mathrm{Cl}}{ }^{-}\right)} \frac{\text { amp-sec }}{\text { drop }}=\text { anodic drop-rate, }
$$

for the anodic drop-rate when the solution of $\mathrm{UO}_{2} \mathrm{Cl}_{2}$ is added at the rate of 1 equivalent of $\mathrm{UO}_{2} \mathrm{Cl}_{2}$ per faraday. When $\mathrm{UO}_{2} \mathrm{Cl}_{2}$ is not added at this rate we have

$\left(\frac{a-c}{a_{\mathrm{UO}_{2}}^{++}}\right)\left(\frac{W F}{\operatorname{amp}(d+e c)}\right) \frac{\text { amp-sec }}{\text { drop }}=$ anodic drop-rate

where $c=$ moles of $\mathrm{H}_{2} \mathrm{O}$ per equivalent weight of $\mathrm{UO}_{2} \mathrm{Cl}_{2}$ actually added to the cell.

Similarly, we may obtain the equation:

$$
\frac{W F}{\operatorname{amp}\left(f+\text { aet }_{\mathrm{UO}_{2}}^{++}\right)} \frac{\text { amp-sec }}{\text { drop }}=\text { cathodic drop-rate }
$$


for the cathodic drop-rate. Here $f=$ moles of $\mathrm{HCl}$ added to the cell per faraday.

In table 1 values of the drop-rates are given for the various concentrations of $\mathrm{UO}_{2} \mathrm{Cl}_{2}$ cited in the introduction and for several values of the current. Two sets of values that will be discussed later are given for the most dilute solution. In these calculations values of $0.258,0.283$ and $0.309^{3}$ were used for the transference number of the $\mathrm{UO}_{2}^{++}$ ion in solutions having, respectively, the normalities of $0.902,0.499$, and 0.1007 .

TABLE 1.-Drop rates for the addition of $\mathrm{UO}_{2} \mathrm{Cl}_{2}$ at the anode and of $\mathrm{HCl}$ at the cathode during the counterflow electrolysis of uranyl chloride a

\begin{tabular}{|c|c|c|c|c|c|}
\hline \multicolumn{3}{|c|}{ At the anode } & \multicolumn{3}{|c|}{ At the cathode } \\
\hline Current & $\begin{array}{l}\text { Weight } \\
\text { of drop }\end{array}$ & $\begin{array}{l}\text { Drop } \\
\text { rate }\end{array}$ & Current & $\begin{array}{l}\text { Weight } \\
\text { of drop }\end{array}$ & $\begin{array}{l}\text { Drop } \\
\text { rate }\end{array}$ \\
\hline \multicolumn{6}{|c|}{$\begin{array}{c}1: 60 \mathrm{U} \mathrm{O}_{2} \mathrm{Cl}_{2} \text { in cell; } 1: 44.5 \mathrm{U} \mathrm{O}_{2} \mathrm{Cl}_{2} \text { added at anode; } 1: 15.5 \mathrm{HCl} \\
\text { added at cathode }\end{array}$} \\
\hline$a m p$ & $g$ & sec/drop & $a m p$ & $g$ & sec/drop \\
\hline 0.3 & 0.0469 & 15.5 & 0.3 & 0.0241 & 24.6 \\
\hline .5 & .0639 & 12.7 & .5 & .0422 & 25.8 \\
\hline .7 & .1172 & 16.6 & .7 & .0573 & 25.0 \\
\hline 1.0 & .1172 & 11.6 & 1.0 & .0573 & 17.6 \\
\hline \multicolumn{6}{|c|}{$\begin{array}{c}\text { 1:110 } \mathrm{U} \mathrm{O}_{2} \mathrm{Cl}_{2} \text { in cell; } 1: 78.9 \mathrm{UO}_{2} \mathrm{Cl}_{2} \text { added at anode; } 1: 31.1 \mathrm{HCl} \\
\text { added at cathode }\end{array}$} \\
\hline 0.3 & 0.0600 & 13.6 & 0.3 & 0.0462 & 24.9 \\
\hline .5 & .1103 & 15.0 & .5 & .0650 & 21.0 \\
\hline \multicolumn{6}{|c|}{$\begin{array}{c}\text { 1:555.1 } \mathrm{U} \mathrm{O}_{2} \mathrm{Cl}_{2} \text { in cell; } 1: 383.5 \mathrm{U} \mathrm{O}_{2} \mathrm{Cl}_{2} \text { added at anode; } 1: 171.5 \\
\mathrm{HCl} \text { added at cathode }\end{array}$} \\
\hline 0.1 & 0.0481 & 6. 5 & 0.1 & 0.0480 & 14.9 \\
\hline .2 & .0751 & 5.1 & .2 & .0480 & 7.4 \\
\hline \multicolumn{6}{|c|}{$\begin{array}{c}\text { 1:555.1 } \mathrm{UO}_{2} \mathrm{Cl}_{2} \text { in cell; } 1: 60 \mathrm{U} \mathrm{O}_{2} \mathrm{Cl}_{2} \text { added at anode; } 1: 171.5 \\
\mathrm{HCl} \text { added at cathode }\end{array}$} \\
\hline 0.1 & 0.0193 & 42. 9 & 0.1 & 0.0480 & 14.9 \\
\hline .2 & .0254 & 28.3 & .2 & .0480 & 7.4 \\
\hline
\end{tabular}

a The rates given in the table are calculated from theoretical principles. In practice, owing to fluctuations in the room temperature, the rates varied somewhat from those given in the table. Also, for current efficiencies considerably below 100 percent, the rates were somewhat different than the theoretical. For example, the rate for the 1:60 solution at a current of 0.5 amp is $12.7 \mathrm{sec} /$ drop. At the beginning the rate was 12.7 and was changed to 12.5 within $7 \mathrm{hr}$ and to 12.0 within an additional $5 \mathrm{hr}$, for platinum anodes. This represents an extreme case wherein there was a definite shift. In general, the rates increased and decreased around the theoretical value over a period of time.

${ }^{3}$ These values were interpolated from the combined data of E. R. Smith and H. Matheson (National Bureau of Standards, Washington, D. C. Jan 28, 1942), of D. A. MacInnes and Associates (Rockefeller Institute for Medical Research, New York City, April 2, 1942), and of C. A. Kraus and Associates (Brown University, Providence, R. I., Oct. 26, 1942)

\section{The Electrolytic Cell and Procedure}

A schematic diagram of the electrolytic cell with auxiliary parts is shown in figure 1 . The cell consisted of a cathode compartment, $A$, and an anode compartment, $B$, separated by a glass wool frit, $I$,

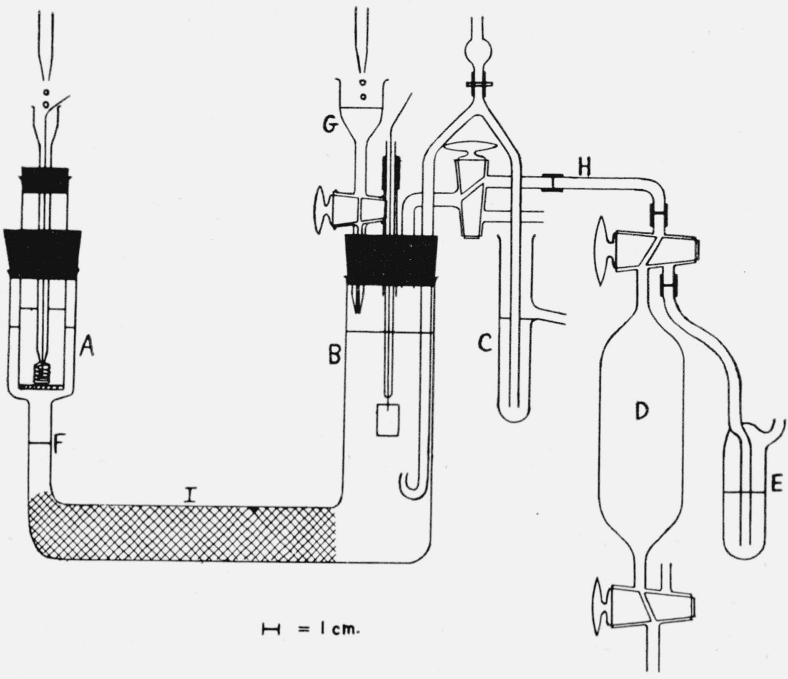

FIgURE 1.-Schematic diagram of the electrolytic cell and gas-sampling pipette with auxiliary equipment.

to prevent diffusion of electrolytic products from one electrode to another. The cell was placed in a water bath to facilitate rapid-heat conduction from the packed tube. The cell was first filled with a solution of $\mathrm{UO}_{2} \mathrm{Cl}_{2}(1: 60)$ to the level marked, $F$. A solution of $\mathrm{HCl}, 15$ percent more dilute than the $1: 15.5$ solution added at the cathode, was carefully poured into the cathode compartment to form a boundary with the solution of $\mathrm{UO}_{2} \mathrm{Cl}_{2}$, and enough solution of $\mathrm{UO}_{2} \mathrm{Cl}_{2}$ added at the anode to fill the cell.

The electrolysis was then started and a $1: 44.5$ solution of $\mathrm{UO}_{2} \mathrm{Cl}_{2}$ was added dropwise to the anode and a 1:15.5 solution of $\mathrm{HCl}$ likewise to the cathode both at the proper rate. A $115-\mathrm{v}$ direct current line was used as the source of electrical power. In the majority of the experiments a current of $0.5 \mathrm{amp}$ was used. In some, a current of $0.3,0.7$, or $1.0 \mathrm{amp}$ was employed, drop rates being adjusted accordingly.

The anode compartment was made air tight. The solution of $\mathrm{UO}_{2} \mathrm{Cl}_{2}$ was introduced through funnel, $G$, carrying a stopcock to prevent air from being drawn into the anode compartment and to prevent escape of the chlorine-oxygen mixture to the atmosphere. A glass tube with stopcock as 
shown led from the anode compartment to a gas sampling pipette, $D$, of about $200-\mathrm{ml}$ capacity, adapted with a trap, $E$, containing 1:60 $\mathrm{UO}_{2} \mathrm{Cl}_{2}$ solution.

As electrolysis proceeded, the chlorine formed at the anode escaped through the tube leading to the pipette and also pushed solution out through the overflow. The $\mathrm{pH}$ of the overflow solution, $C$, was measured with a Beckman $\mathrm{pH}$-meter at frequent intervals during the electrolysis. The initial $\mathrm{pH}$ of 1.44 decreased gradually within 3 hours to 1.38 and thereafter remained constant at 1.38 , indicating that the solution in the anode compartment had become saturated with chlorine gas. When the $\mathrm{pH}$ of the overflow had attained an equilibrium value, the gas in the anode was permitted to flow for about one-half hour $(228 \mathrm{ml}$ of $\mathrm{Cl}_{2}$ are evolved per hour at $25^{\circ} \mathrm{C}$ and $1 \mathrm{~atm}$ at a current of $0.5 \mathrm{amp}$ ) through tube, $H$, and trap, $E$, to flush out all the confined air. Then samples were drawn into the evacuated pipette, $D$, at a very slow rate. For all the determinations, 1/1/2 to 2 hours were taken to fill the pipette. As the gas was drawn into the pipette, the solution in the overflow $\left(\mathrm{Cl}_{2}\right.$ saturated) was drawn into the anode compartment. The pipette stopcock was then closed, solution was forced out of the anode compartment into the overflow by the generated gas and the added solutions, and the procedure repeated approximately 22 times at intervals from 4 to 5 minutes (volume of the overflow cup was about $1 / 22$ of the volume of the pipette; 22 fillings being required). An indication of the pressure of chlorine-oxygen mixture in the pipette was given by the head of the overflow solution; when no flow of gas occurred it was known that the pipette was filled with gas.

The gas collected in the pipette was analyzed by absorption in a $1.0 \mathrm{~N}$ solution of $\mathrm{KOH}$, which rose from a beaker into the pipette as the chlorine dissolved. Corrections were made for the air contained in the entrance tube for $\mathrm{KOH}$, and the pressure of the residual gas (oxygen) that did not dissolve was corrected to 1 atmosphere pressure, using the recorded barometric pressure and the difference in the heights of the two $\mathrm{KOH}$ levels. The total volume of gas and the volume of $\mathrm{Cl}_{2}$ were determined from the known weights of the pipette, the pipette filled with water, and pipette containing the various amounts of $\mathrm{KOH}$. The density of the $\mathrm{KOH}$ solution was determined with the pipette in like manner.

In the above, the procedure was described for the electrolysis of a 1:60 solution of $\mathrm{UO}_{2} \mathrm{Cl}_{2}$. The procedure for the electrolysis was the same for the more dilute solutions with exception of the 0.1007 $N$ solution. In the first experiment a $1: 383.5$ solution of $\mathrm{UO}_{2} \mathrm{Cl}_{2}$ and a $1: 171.5$ solution of $\mathrm{HCl}$ were added, respectively, to the anode and cathode compartments. However, it was found that the rates of addition of these solutions were nearly equal to the rates of evolution of and subsequent saturation of the solution with $\mathrm{Cl}_{2}$, so that nearly all the evolved $\mathrm{Cl}_{2}$ was lost in maintaining equilibrium. Consequently, attainment of equilibrium was exceedingly slow. In later experiments, therefore, a 1:60 solution of $\mathrm{UO}_{2} \mathrm{Cl}_{2}$ was added at the anode at a slower rate calculated by eq $5 \mathrm{a}$. Attainment of equilibrium was then more rapid.

Another factor had to be considered. Above it was stated that a solution of $\mathrm{HCl}, 15$ percent more dilute than that added at the cathode, was used in forming the boundary. This was necessary to assure a sharp boundary between the solutions of $\mathrm{HCl}$ and $\mathrm{UO}_{2} \mathrm{Cl}_{2}$. The concentration of $\mathrm{HCl}$ required is given by the regulating function of Kohlrausch [2]:

$$
\frac{C_{\mathrm{H}}^{+}}{t_{\mathrm{H}}^{+}}=\frac{C_{\mathrm{UO}_{2}^{++}}}{t_{\mathrm{UO}_{2}^{++}}}
$$

where $C$ represents the equivalent concentration of the ions denoted by subscripts. For 1:15.5, $1: 31.1$, and $1: 171.5$ solutions of $\mathrm{HCl}$, the transference number of the $\mathrm{H}^{+}$ion is, respectively, $0.844,0.838$, and 0.832 [4]. Consequently, the normality of $\mathrm{HCl}$ for use with solutions of $\mathrm{UO}_{2} \mathrm{Cl}_{2}$ of normality 0.902, 0.499, and 0.1007 must be, respectively, $2.95,1.49$, and 0.271 . Consequently, the $1: 15.5,1: 31.1$, and $1: 171.5$ solutions of $\mathrm{HCl}$ were made 15 percent more dilute with water (densities of $\mathrm{HCl}$ solutions from reference [3]). A closer adjustment of the concentration was not necessary. Theoretically, it would appear that any concentration of $\mathrm{HCl}$ could be used because of an automatic adjustment of the speed of the ions arising from variable potential gradients at the junction. However, MacInnes and Smith [5] have shown experimentally that the concentrations of the two solutions in contact must conform to eq 7 within about 10 percent. The 15-percent 
dilution is well within this limit. Furthermore, owing to the hydrolysis of $\mathrm{UO}_{2} \mathrm{Cl}_{2}$ and dissolved $\mathrm{Cl}_{2}$, some hydrogen ions migrate across the boundary between $\mathrm{HCl}$ and $\mathrm{UO}_{2} \mathrm{Cl}_{2}$ under the influence of the electric field. In practice the boundary was steady, slight adjustments being made from time to time in the cathodic drop-rate when the houndary showed a tendency to move toward or away from the cathode. For the present purpose the adjustment of the boundary was adequate.

\section{Current Efficiencies}

In tables 2 and 3 the current efficiencies (percentage yield of $\mathrm{Cl}_{2}$ ) are given for different electrode materials at several current densities and for various concentrations of $\mathrm{UO}_{2} \mathrm{Cl}_{2}$. The precision of the method is illustrated by data given in table 4 . The precision of the method is high and of the order of 0.1 to 0.2 percent. The current efficiencies obtained in this way are higher than those obtained by the usual methods, in which insufficient time is allowed to assure equilibrium between the gas and liquid phases. In table 5 some data are given to show the effects of time of electrolysis and anodic-cathodic mixing on the values of the current efficiency. Low values are obtained if the current efficiency is determined before equilibrium has been obtained. The introduction of $\mathrm{HCl}$ from the cathode raises the current efficiency for two reasons: the acidity of the solution is increased and the total concentration of $\mathrm{Cl}^{-}$ions is raised. The values of the current efficiency given here may be considered as minimum values, as any leaks in the apparatus would lower and not raise the values.

TABLE 2.-Anodic current efficiencies in the counterflow electrolysis of $0.902 N(1: 60)$ solutions of uranyl chloride.

The graphites were of different commercial grades

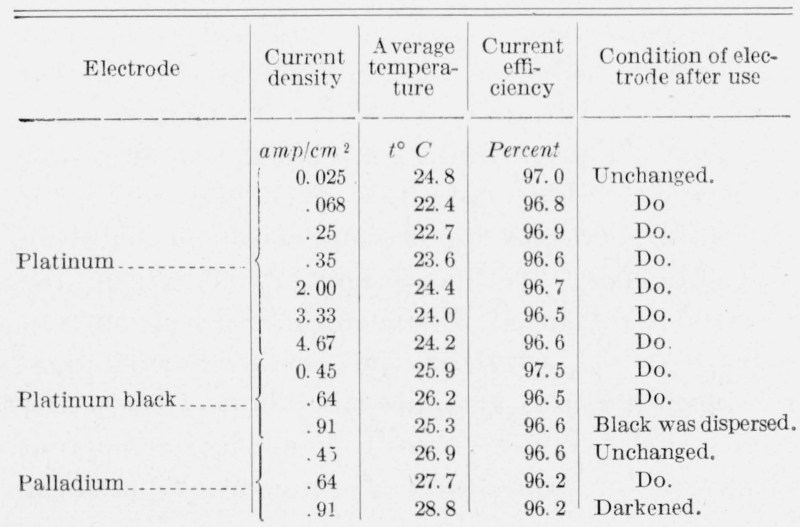

TABLE 2.-Anodic current efficiencies in the counterflow electrolysis of $0.902 N(1: 60)$ solutions of uranyl chloride.Continued

The graphites were of different commercial grades

\begin{tabular}{|c|c|c|c|c|}
\hline Electrode & $\begin{array}{l}\text { Current } \\
\text { density }\end{array}$ & $\begin{array}{l}\text { A verage } \\
\text { tempera- } \\
\text { ture }\end{array}$ & $\begin{array}{l}\text { Current } \\
\text { effi- } \\
\text { ciency }\end{array}$ & $\begin{array}{l}\text { Condition of elec- } \\
\text { trode after use }\end{array}$ \\
\hline \multirow{4}{*}{ Palladium black ...... } & $a m p / \mathrm{cm}^{2}$ & $t^{\circ} C$ & Percent & \\
\hline & $\int .45$ & 30.0 & 96.5 & Unchanged. \\
\hline & .64 & 30.3 & 96.4 & Black was dispersed. \\
\hline & .04 & 28. 3 & 96.9 & Unchanged. \\
\hline \multirow{3}{*}{$\begin{array}{l}\text { Iridium } \\
\text { Platinum } 80 \% \text {, irid- } \\
\quad \text { ium } 20 \% \text {. }\end{array}$} & .08 & 29.2 & 96.3 & Do. \\
\hline & .50 & 26. 1 & 96.5 & Do. \\
\hline & .092 & 30.3 & 96.4 & Unchanged. \\
\hline \multirow{2}{*}{ Magnetite .. } & .18 & 26.0 & 73.6 & Eroded. \\
\hline & .50 & 26.5 & 57.3 & Do. \\
\hline \multirow{3}{*}{ Zirconium carbide.... } & .36 & 28. 2 & 96.5 & Etched. \\
\hline & .44 & 28.6 & 96.0 & Do. \\
\hline & .51 & 25. 7 & 95. 7 & Do. \\
\hline \multirow{3}{*}{ Tungsten carbide..... } & .056 & 25.1 & 96.7 & Etched. \\
\hline & .08 & 25.3 & 94.5 & Do. \\
\hline & .38 & 25.0 & 87. 1 & Do. \\
\hline \multirow{3}{*}{$\begin{array}{l}\text { Columbium-tantalum } \\
\text { carbide. }\end{array}$} & .38 & 26. 7 & 95.5 & Slightly etched. \\
\hline & .53 & 27. 9 & 95.9 & Do. \\
\hline & .75 & 26. 2 & 95.1 & Do. \\
\hline \multirow[t]{3}{*}{ Are carbon } & .10 & 25. 2 & 89.7 & Pencilled. \\
\hline & .012 & 23.9 & 97.4 & Unchanged. \\
\hline & .017 & 24.0 & 96.5 & Do. \\
\hline \multirow[t]{3}{*}{ Graphite I. - } & .45 & 22. 7 & 86.5 & Do. \\
\hline & .64 & 25. 2 & 86.0 & Do. \\
\hline & .90 & 25.1 & 85.6 & Disintegrated. \\
\hline \multirow{3}{*}{ Graphite II $\ldots \ldots$} & .14 & 30.7 & 90.0 & Unchanged. \\
\hline & .64 & 28.9 & 86.7 & Do. \\
\hline & 1. 25 & 29. 9 & 85. 7 & Disintegrated. \\
\hline \multirow{2}{*}{ Graphite III .. } & 0.14 & 28.8 & 92.2 & Do. \\
\hline & .64 & 29.3 & 84.1 & Do. \\
\hline Graphite IV . & .45 & 29. 7 & 86.6 & Do. \\
\hline Graphite V . ......... & .45 & 27.1 & 88.8 & Do. \\
\hline
\end{tabular}

TABLE 3.-Anodic current efficiencies in the counterflow electrolysis of $0.498 \mathrm{~N}$ and $0.1 \mathrm{~N}$ solutions of uranyl chloride

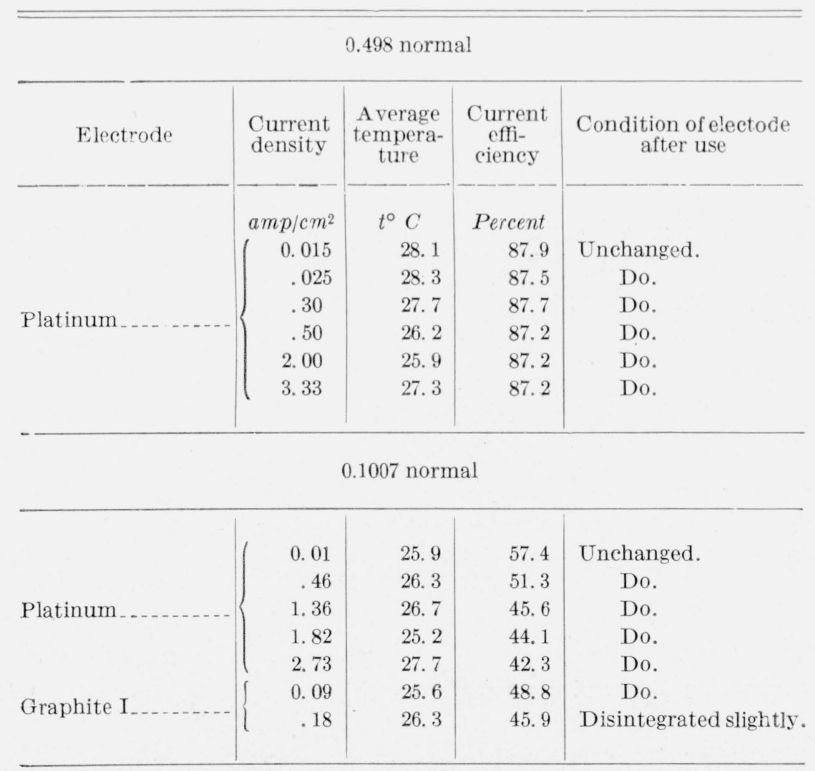


TABLE 4.-Data showing the precision of method for determinations of anodic current efficiencies

\begin{tabular}{|c|c|c|c|c|c|}
\hline \multicolumn{2}{|c|}{ Part I: platinum electrodes in 0.902 N solutions of uranyl } \\
chloride
\end{tabular}

s Obtained with arc-carbon electrodes in $0.841 \mathrm{~N}$ solution of uranyl chloride.

TABLE 5.-Nonequilibrium values showing the effects of time and anodic-cathodic mixing on anodic current efficiencies

(Electrodes of platinum and $0.1 \mathrm{~N}$ solutions of $\mathrm{U} \mathrm{O}_{2} \mathrm{Cl}_{2}$ were used).

\begin{tabular}{|c|c|c|c|c|}
\hline \multicolumn{5}{|c|}{ Effect of the time of electrolysis } \\
\hline $\begin{array}{l}\text { Time of } \\
\text { current } \\
\text { flow }\end{array}$ & $\begin{array}{l}\mathrm{pH} \text { of the } \\
\text { overflow }\end{array}$ & $\begin{array}{l}\text { Current } \\
\text { density }\end{array}$ & $\begin{array}{l}\text { Current } \\
\text { efficiency }\end{array}$ & $\begin{array}{l}\text { Equilib- } \\
\text { rium } \\
\text { value of } \\
\text { current } \\
\text { efficiency }\end{array}$ \\
\hline Hours & & $A m p / c m^{2}$ & Percent & Percent \\
\hline 2.0 & 1.67 & 1. 36 & 8. 2 & 45.6 \\
\hline 7.0 & 1. 56 & 1.82 & 18.0 & 44.1 \\
\hline 12.0 & 1. 54 & 1.82 & 28.2 & 44.1 \\
\hline 24.0 & 1. 52 & 2.27 & 39.3 & 42.3 \\
\hline 26.5 & 1. 52 & 2. 73 & 42.3 & 42.3 \\
\hline 28.0 & 1. 52 & .01 & 57.5 & 57.4 \\
\hline 33.0 & 1.54 & .01 & 55.0 & 57.4 \\
\hline 36.0 & 1. 52 & 1.82 & 44.1 & 44.1 \\
\hline 40.0 & 1. 52 & .01 & 57.5 & 57.4 \\
\hline 42.0 & 1. 52 & 1.82 & 43.9 & 44.1 \\
\hline \multicolumn{5}{|c|}{ Effect of anodic-cathodic mixing } \\
\hline a 11.5 & 0.98 & 1.82 & 84.7 & 44.1 \\
\hline 26.0 & .51 & 1. 82 & 91.1 & 44.1 \\
\hline 30.0 & .58 & 1.82 & 90.3 & 44.1 \\
\hline 31.5 & 1. 32 & 1.82 & 67.9 & 44.1 \\
\hline b 36.0 & 1. 52 & 1.82 & 44.1 & 44. 1 \\
\hline
\end{tabular}

a This value and all those that follow are the hours of current flow after anodic-cathodic mixing.

b No anodic-cathodic mixing.
The current efficiency is the same within a few tenths of 1 percent for electrodes of the platinum group and is practically independent of the current density for the most concentrated solutions. For the most dilute solution the current efficiency increases as the current density is decreased. For the other electrode materials the current efficiency is lower. These electrodes for the most part deteriorate with use. Magnetite, in agreement with some observations recorded in the literature [6] deteriorated rapidly forming a cloudy solution. This may explain the abnormally low values of current efficiency obtained with their use. Platinum black and palladium black loosened on use; the black was probably dispersed in the electrolyte.

When the current efficiencies are plotted with respect to the normality of the solutions they approach asymptotically 100 percent as the normality of the solution is increased. This suggests that current efficiencies of 100 percent probabiy cannot ve realized in the electrolysis of aqueous solutions of uranyl chloride at $25^{\circ} \mathrm{C}$.

\section{Conclusions}

The oxidation potentials for the chloride ion and for the water reaction are respectively -1.359 $\mathrm{v}[7]$ and $-1.229 \mathrm{v}[8]$ at their standard states.

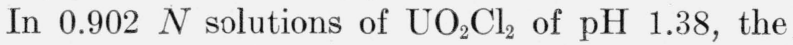
oxidation potentials of these two oxidation steps are, respectively, $-1.379 \mathrm{v}$ and $-1.147 \mathrm{v}$. The activity coefficient of $\mathrm{UO}_{2} \mathrm{Cl}_{2}$ was taken equal to that of $\mathrm{CaCl}_{2}$ [9] of equivalent concentration. For a partial pressure of oxygen of $0.033 \mathrm{~atm}$. the latter value would be $-1.125 \mathrm{v}$. Thus, even in concentrated chloride solutions, oxygen should be more readily liberated than chlorine. However, because of the bigh oxygen overvoltage, chlorine is evolved.

The percentage yield of chlorine should be greater at those electrodes having the higher oxygen overvoltage and the lower chlorine overvoltage. (The meaning of chlorine overvoltage is obscure. The potential over the reversible potential necessary for chlorine evolution is probably influenced by the presence of oxygen on the electrode surface.) For example, at a current density of $0.1 \mathrm{amp} / \mathrm{cm}^{2}$ the oxygen overvoltages for platinum and graphite are about $1.28 \mathrm{v}$ and $1.09 \mathrm{v}[10]$. These values indicate higher current efficiency for production of chloride at platinum 
electrodes. The chlorine overvoltages for platinum and graphite at the same current density are approximately $0.054 \mathrm{v}$ and $0.25 \mathrm{v}$ [10], which likewise indicate higher efficiency at platinum electrodes.

The difference between the overvoltages of oxygen and chlorine is about the same at all current densities for both platinum and graphite (for graphite, the difference decreases slightly with current density), indicating the same efficiency at all current densities. This fact is substantiated by the data for platinum but not for graphite. The latter is probably affected by absorption of evolved gases. If the overvoltage relationships strictly apply, platinum and probably other metals of the platinum group would be the best materials for anodes in the electrolysis of uranyl chloride. However, current efficiencies of 100 percent are not obtained with these electrodes even in concentrated solutions. Hence, simultaneous electrode reactions occur at the anode with the attendant complications arising from changes in acidity and reactions between the electrode products and the electrolyte.

\section{References}

[1] A. K. Brewer, S L. Madorsky and J. W. Westhaver, Science 104, 2694 (1946).

[2] F. Koh!rausch, Ann. Physik. 62, 209 (1897).

[3] J. A. Beattie, Int. Crit Tables, III, 54 (1928).

[4] K. G. Falk, Int. Crit. Tables, VI, 309 (1929); H. S. Harned and E. C. Dreby, J. Am. Chem. Soc. 61, 3113 (1939).

[5] D. A. MacInnes and E. R Smith, J. Am. Chem. Soc 45, 2246 (1926), 46, 1398 (1924).

[6] C. L. Mantell, Industrial electrochemistry, p. 107, 118, 336 (McGraw-Hill Book Co., Inc., New York, N. Y., 1940).

[7] D. A. MacInnes, The principles of electrochemistry, p. 199 (Reinhold Publishing Corp., New York, N. Y., 1939).

[8] S. Glasstone, An introduction to electrochemistry, p. 242 (D. VanNostrand Co., Inc., New York, N. Y., 1942).

[9] R A. Robinson, Trans. Faraday Soc. 36, 735 (1940).

[10] M Knobel Int Crit. Tables, VI, 340 (1929).

Washington, April 30, 1946. 